2

US. Department of Transportation

National Highway Traffic Safety Administration

\section{A Manual for Managing Community Alcohol Safety Education Campaigns}




\section{A Manual for Managing Community Alcohol Safety Education Campaigns}




\section{Contents}

Chapter I: $\quad$ The Automobile and Alcohol in Daily Life . . . . . . 1

Chapter II: $\quad$ Developing A Communications Plan .......... 3

Chapter III: $\quad$ Defining Objectives . . . . . . . . . . . . . . . . . 5

Chapter IV: Identifying Target Audiences.............. 7

$\begin{array}{lll}\text { Chapter V: } & \text { What Every Program Needs: Community Support. . } & 9\end{array}$

Chapter VI: What Does Your Community Know About

Drunk Driving? ........................ 13

Chapter VII: Carrying Out A Campaign That Works . . . . . . . . 19

Chapter VIII: Working With The Media/Person-To-Person

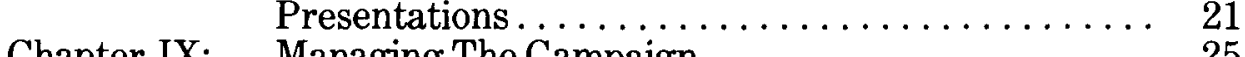

Appendix A: Capsule Communications Plans For Target Audiences ................ 27

Appendix B: A Sample Survey Questionnaire .......... 35

Bibliography . . . . . . . . . . . . . . . . . . 40

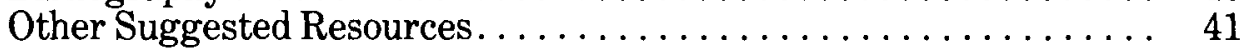




\section{The Automobile and Alcohol in Daily Life}

There are almost as many cars as people in this country. America is a lot of freewheeling adults and teenagers who have been raised on the importance of automobiles from kiddie cars to $280 \mathrm{Z}$ 's. Most of us wouldn't think of being without a car. The romance of the car has replaced the romance of the wilderness. To get from one place to another we've given up the beaten paths for ribbons of concrete. We scheme and dream about cars and the places they'll take us. Like cars, alcohol is also a national institution. It's everywhere from the corner bar to Embassy Row. Weddings, christenings, anniversaries, parties, holidays - all are occasions for drinking. Some people even invent holidays to have a reason to drink. And the cocktail party surely oils society's wheels.

Both cars and alcohol have a place in our society. When used separately, each can provide pleasure and satisfy needs. But when used together they spell disaster! Without the problems they create together there wouldn't be any need for this manual. But there is. Nearly half of all fatal car accidents involve people who have been drinking.

\section{Alcohol and Death on the Road: The Need for Change}

Another fact: alcohol-related car accidents are the number one killer of Americans under age 40 .
Over 40, the numbers go down in comparison with heart disease, strokes, and cancer, but the figures are still shockingly high.

Life-styles are changing. We jog, give up smoking, cook our food in vegetable oil, diet, etc. But people still slide behind the wheel after too many drinks. Even if you don't, you sometimes may find yourself on the road with someone who has. Ignorance is part of the problem. Many people simply don't know what a drunk driver is. They don't know that drunkenness is determined by a fixed ratio of alcohol to body weight (BAC, or blood alcohol concentration).

Some people look upon an ability to hold their liquor as a matter of pride. Some of us feel that acknowledging we're intoxicated is the same thing as saying that we're weak. So ignorance is only part of the problem. Even when we know the facts, there are still social norms and expectations that contribute to drunk driving.

\section{Social Factors That Contribute to Drunk Driving}

Eighty-five percent of the adults surveyed by NHTSA a few years ago rated drunk driving as an extremely or very important social concern. Nonetheless, there's a considerable gap between recognition of the problem and willingness to take personal action to prevent a drunk from driving.
Words don't always translate into deeds.

We tell each other it is a serious problem, but our drinking and driving behavior tell a different story. Party hosts and hostesses, bartenders, individual drinkers all continue to serve or down beers, vodka gimlets, screwdrivers, manhattans and everything else in growing quantities. More people drink more alcohol, beginning at younger ages, than ever before. And even more people are driving when they're drunk.

Is it only a personal problem of the other fellow? We serve enough liquor to make a guest drunk but then are afraid or reluctant to keep him or her from driving home. We don't want to offend. Maybe we think it isn't any of our business.

Thoughts like that are what we must change. NHTSA has come up with a slogan currently being used in its national public information campaigns:

\section{FRIENDS DON'T LET} FRIENDS DRIVE DRUNK. That says it all. But even when people are willing to do something, they don't always recognize themselves to be in a drunk-driving situation. If they do see the problem, they don't always know what specific things they can do Social attitudes about drunk driving are deeply ingrained in our behavior. But change them we must if we are to keep more and more people 
from dying and being injured as a result of drunk-driving accidents.

This manual offers help to those who want to work for change.

\section{Pilot Community Education Projects}

NHTSA sponsors extensive public service advertising to reach people through the national media. This advertising has been supplemented by pilot action projects in 35 communities across the country. Many of these Alcohol Safety Action Projects (ASAPs) are still in operation, funded by their own communities.

When these ASAPs were just established the political, professional, and economic resources of the entire community were brought into play. Emphasis was placed on a variety of countermeasures, including public information and education, law enforcement, adjudication, rehabilitation, program management, and evaluation. During the past five years data have been collected about the effects of many ASAP countermeasures. The data show that ASAPs which directed their campaigns to some specific issue (for example, teenaged drinking) showed positive results more often than ASAPs which took a more general approach.

\section{You Can Make A Difference}

Public information can make a dif- ference. NHTSA continues to operate a national public information program to persuade people that intervening to prevent drunk driving is acceptable and responsible social behavior.

How does a community education program get started? It starts with people like you, who are willing to develop a systematic program that responds to the alcohol safety education needs of your community.

When you take charge you will wear a lot of hats:

- Pollster - to assess the community drunk-driving problem. - Planner - to set objectives and establish priorities.

- Producer - to design educational materials and programs.

- Manager - to persuade influential people to support a community education program with money and professional resources.

- Consultant - to inform a community about its drunk-driving problem and national education programs directed toward reducing the problem.

- Coordinator - to find and manage resources within the community to combat drunk driving. - Agitator - to raise the issue of drunk driving and provoke people to become concerned.

The following pages suggest specific activities for each of these roles. 


\section{Developing a Communications Plan}

Most experienced communicators find it beneficial to begin a campaign with a written plan that clearly identifies:

- What has to be done;

- Who you can get to do it;

- How you can get them to do it.

These elements are usually discussed in terms of objectives, target audiences, and strategies. A written plan makes it easier to:

1. Establish a shared understanding of the communications effort, including specific objectives against which the campaign can be measured;

2. Set priorities for activities and resources;

3. Establish a time frame for scheduling activities and measuring results.

This manual includes a general communications plan that will help you identify objectives, target audiences, and strategies for your plan. What is suggested here, however, is not intended to replace a specific written plan addressed to the needs of your own community.

You will determine objectives. You will decide on target audiences, on the specific activities you undertake to try to reach them, and on the time you allow for these activities. Substantial resources are required to operate comprehensive, full-fledged community education programs for all seventeen target audiences identified in this manual. Your budget and staff are likely to be more modest in scale. As a result, you will not be able to reach all the potential target audiences.

Thus, a survey of drinking attitudes and behavior in your own community is the first step. This survey will help you select the most important target audiences in your area and the kinds of behavior you wish to change. Eliminate audiences that your survey identifies as having little relation to the drunk-driving problem, and focus your efforts on groups that will benefit more from your efforts.

After you decide which groups and types of behavior require the mosi attention, make a schedule alloting a certain portion of your time for each one. The day-to-day operating part of your plan will consist of trying to achieve the maximum impact at the lowest cost in the shortest time. The following outline will help you set your own priorities.

\section{Outline for a General Communications Plan}

\section{Introduction}

Background Your state and local Department of Motor Vehicles will be helpful in assembling background information on local roads and highways. This ought to include the history of earlier safety programs.

Research Findings What are the traffic accident and fatality statistics in your state and community, and how do these compare with other areas? What are the recorded causes of traffic accidents and deaths in your community? If surveys of public attitudes on highway safety have been conducted, what were the results?

\section{Overall Objectives}

Traffic Safety Objectives Existing highway safety program plans can give you the essential framework for establishing overall highway safety objectives. For example, one objective might be to reduce alcohol-related accidents by 10 percent. The ultimate objective of any highway safety program is to reduce the number of traffic accidents and fatalities.

\section{Public Information Objectives} The public information programs you undertake will be aimed at changing specific attitudes and behavior regarding alcohol that contribute to highway crashes.

\section{Public Information and Education Strategies}

Identifying Target Audiences People who participate in 
business and social drinking and other people who can influence public behavior are your target audiences. These target audiences are discussed later in more detail.

Defining What You Want Target Audiences To Do Once you identify a target audience you need to define what behavior you want this audience to change or what social influence you want them to exert.

\section{Mobilizing Community Support} Active, vocal support from public officials and community leaders will help you gain public support and access to the media. Identify key persons and involve them in your program.

Surveying Community Attitudes Survey results can tell you how much your community knows about the relationship between alcohol and highway accidents. They are useful in all aspects of your campaign as you determine what you want to say, who you want to say it to, and how you want to say it.

\section{Development of Programs}

Campaign Description Describe the campaign for each target audience in priority order. Objectives, strategies, and media applicable to each audience should be included.

Schedule List the components for each campaign and set a specific schedule for launching and completing each one.

\section{Media Merchandising}

\section{Distribution and Placement} Describe which media will be used to reach general and special audiences. Explain why those media were chosen and when and how materials will be distributed to the media.

\section{Consultation and Coordination}

Local Agencies There may be other groups in your area that are involved in highway safety programs. Learning about the activities and materials of these groups (and others around the country) will help you to develop your own program plans.

State Agencies Every state has a highway public information and education program. Find out how the program operates and examine the materials used in the program.

National Agencies In addition to highway safety programs run by the federal government, there are many national groups that may be willing to assist you, such as safety councils, auto clubs, and councils on alcoholism.

Others Business and Civic organizations and volunteer agencies may be of help. Free or inexpensive local resources should be utilized. For example, there may be no staff members available to conduct an evaluation, but local universities may be willing to help in developing one.

\section{Evaluation}

Measuring Campaign Effects By comparing the results of the surveys taken after the campaign with those taken before it was launched, it is possible to measure changes in knowledge, attitude, and behavior. The communications plan should describe the survey method to be used (telephone interview, household interview, roadside interview, interview of driver's license applicants).

Measuring Media Support Radio, television, and newspapers should be reviewed regularly to determine when your program's public service messages appear. The media can also compute the dollar value of this free advertising. Stations will tell you how long your message should be and when it will be used.

\section{Personnel}

Staff Describe in detail who is responsible for specific tasks and how supervision will be maintained. Include provisions for consultants (rather than full-time staff members) as needed.

Volunteer Assistance Volunteers from civic organizations, women's groups, schools, and professional organizations can be recruited for many tasks, ranging from distributing materials to conducting interviews and speaking before community organizations.

\section{Finances}

Budget The budget should specify funds available and the costs of each proposed activity. Major expenditure categories will include staff, materials (paper stock, film, stationery supplies, etc.), production (filming, reproduction, artwork, keypunch, computer time), telephone, equipment (film and slide projectors), breath analyzers, office space, and travel.

\section{Conclusion}

If you adapt this general outline and the information contained in this manual to your own needs and resources, you will have a communications plan that can: 1. Provide a tool for managing the communications program; 2. Enlist others in the effort; 3. Build credibility (there's that word again) for your organization. 


\section{Defining Objectives}

The task of developing a community education program may seem awesome and complicated. But you can reduce potential complications by carefully establishing the program's foundation. This means avoiding pressure to conduct a do-good publicity campaign. Instead, carefully identify objectives that lend rationality and meaning to your program.

In defining the purpose of your program, don't expect miracles. Most authorities in traffic safety agree that significant reductions in alcohol-related traffic accidents occur only over the long term. Community education should be seen as a continuing effort.

Your general goal of traffic safety can only be achieved through a series of progressive objectives. Think in terms of the most immediate needs (for example, obtaining financial support) that must be satisfied before you can address other objectives. $\mathrm{Ob}$ jectives should build on one another. As each one is achieved, your target audiences will move closer toward more responsible behavior.

Figure 1 at the end of this chapter illustrates the cumulative nature of well-defined objectives. This figure shows the movement from immediate practical objectives through intermediate levels toward the long-range goal. Again - make sure the objectives are realistic, meaningful, and clear.

\section{What Needs To Be Done?}

Whatever the scope of your educational program, your desire is to impress upon people the facts about drinking and driving. You want to convince people of the extent to which personal attitudes and behavior contribute to traffic accidents. And you want to persuade them to do something to reduce the problem.

NHTSA conducted a nationwide survey of public attitudes toward drinking and driving in 1974. This comprehensive survey uncovered a puzzling inconsistency. A majority of Americans drink alcoholic beverages, and most people consume from three to nine drinks once a week or more. Yet more than half of all drinkers said they were not involved in any situation during the entire year preceding their interview that involved drunk driving.

Given the regular pattern of drinking and the large amounts of alcohol consumed over a year's time, this appeared to be a statistical impossibility. Ultimately it was discovered that most people fail to recognize the situation because they don't know how to tell when they themselves or someone else is too intoxicated to drive.

Myths about drinking permeate the popular culture. The failure to recognize drunk-driving situations is largely due to misconceptions about the effects of alcohol and the remedies for intoxication. Of those interviewed in the NHTSA survey: - 52 percent believed that you could sober up by drinking a cup of strong, black coffee; - 68 percent believed that a cold shower would eliminate the effects of alcohol;

- 70 percent believed that a can of beer is less intoxicating than an average drink of liquor; - 80 percent believed that sticking with one kind of drink was less intoxicating than mixing drinks.

Since myths like these contribute to personal attitudes and behavior, you must design a community education program that will destroy these myths and at the same time outline specific actions people can take to prevent drunk driving. For example, if you're the host at an event where alcohol is served, you might:

- Serve food to slow the effects of alcohol;

- Close the bar an hour before guests drive home;

- Avoid pushing alcoholic beverages;

- Have soft drinks available as alternatives.

If a guest becomes intoxicated in spite of these precautions, you may:

- Drive the alcohol-impaired person home;

- Take his or her car keys and send them home in a taxi;

- Have him or her spend the night at your house.

These are actions that can be taken by friends and relatives as well as hosts. 
Fig. 1 What Needs to be Done: A Step by Step Approach to the Ultimate Goal

\begin{tabular}{|c|c|}
\hline & $\begin{array}{l}\text { Reduce number and severity of alcohol- } \\
\text { related traffic accidents. }\end{array}$ \\
\hline ర్ & $\begin{array}{l}\text { Increase number of groups who adopt } \\
\text { responsible drinking and driving policies. }\end{array}$ \\
\hline & $\begin{array}{l}\text { Reduce number of persons driving while } \\
\text { intoxicated or impaired. }\end{array}$ \\
\hline & $\begin{array}{l}\text { Increase number of people who drink and drive } \\
\text { responsibly. }\end{array}$ \\
\hline & $\begin{array}{l}\text { Increase number of persons who say they do } \\
\text { intervene to prevent drunk driving. }\end{array}$ \\
\hline & $\begin{array}{l}\text { Increase number of persons who express willingness } \\
\text { to intervene to prevent drunk driving. }\end{array}$ \\
\hline & $\begin{array}{l}\text { Win Acceptance of specific intervention actions to } \\
\text { prevent drunk driving. }\end{array}$ \\
\hline & $\begin{array}{l}\text { Increase number of persons who acknowledge drunk } \\
\text { driving as an issue of personal responsibility. }\end{array}$ \\
\hline & $\begin{array}{l}\text { Personalize problem of drunk driving for selected target } \\
\text { audiences. }\end{array}$ \\
\hline & $\begin{array}{l}\text { Increase level of alcohol/driving knowledge among selected } \\
\text { target audiences. }\end{array}$ \\
\hline & $\begin{array}{l}\text { Expand awareness of potency of beer, wine and liquor among } \\
\text { selected audiences. }\end{array}$ \\
\hline & $\begin{array}{l}\text { Improve understanding about alcohol and its effect on the body } \\
\text { and driving skills among selected target audiences. }\end{array}$ \\
\hline & $\begin{array}{l}\text { Increase knowledge of seriousness of drunk-driving problems } \\
\text { among selected target audiences. }\end{array}$ \\
\hline & Achieve community awareness of program and its purposes. \\
\hline$\dot{c}$ & Obtain financial backing for program. \\
\hline 宽 & $\begin{array}{l}\text { Gain support of influential community members for alcohol-driving } \\
\text { education program. }\end{array}$ \\
\hline
\end{tabular}




\section{Identifying Target Audiences}

Once you know what needs to be done, the next task is to identify who you can get to do it. Who are the people who participate in business and social drinking? Who are the people who serve alcohol? Who enforces the law and sentences the offender? Who are the people who influence public behavior? The groups that can be named in answer to these questions are all potential target audiences.

The experience of other ASAP projects indicates that there are 17 major target groups for a community education program. In all probability, your community will have the same major target groups. But before any attempt is made to communicate with these groups about alcoholism and drunk driving, you'll want to consider the importance of each group to your final goal. If funds are limited, there may be certain groups whose importance to your program demands that they be contacted first.

An example will make this clearer. Hosts and hostesses, tavern owners and bartenders, and liquor store operators might all be named in response to the question, "who are the people who serve alcohol?" And in many communities all three groups will be obvious target audiences for campaigns against drunk driving. But you will have to decide whether all three warrant equal attention in your community.
It may be, for example, that in your community most people drink at home or at the homes of friends, and that there are few bars and taverns. If this should be the case, hosts and hostesses and liquor store operators will be primary target groups, with little attention being given to tavern operators and employees.

Any attempt to identify target audiences will probably begin with the two most obvious onesall adults, on the one hand, and on the other hand the young people of the community who are on the threshhold of or moving into adulthood. For the purposes of a campaign like that discussed here, this second group will probably include those between the ages of 16 and 25 .

The importance of these two groups is evident. The adult audience will include all those adults who are likely to be involved in alcohol-related situations. Thus, a campaign directed toward all adults can reach all those most likely to interact with potential or actual drunk drivers. A campaign that also addresses youth, however, will probably be more effective. The statistics show that young people are involved in alcohol-related car accidents out of all proportion to their number of licensed drivers.

In all probability you will want to move beyond these two broad target audiences to direct your message at all or many of the other groups able to influence behavior. If young people in your community clearly pose a drinking problem you may want to choose parents and teachers as other target audiences. Both of these groups have a responsibility to convey responsible social values to young people and are in a good position to do so.

Assuming, on the other hand, that it is adults who constitute the major drunk driving problem in your community, the selection of target audiences will vary accordingly. In this situation the most logical chief target groups for your message may be the news media, hosts and hostesses, business organizations, and volunteer organizations (women's groups or service clubs, for example).

There are many other potential target groups. You may discover from your analysis of the drunk driving problem in your community that the police department is inclined to ignore the problem. Or it may be that the police are committed to attacking the problem but that the courts are not. You should select target groups accordingly.

Lawyers, physicians, pharmacists, social workers, and the clergy all compose groups of people whose members are likely to come into contact with the actual or potential drunk driver. Your message can make each of these groups more sensitive to the prob- 
lem and how to deal with it.

Last, but not necessarily least, are problem drinkers and alcoholics themselves, along with their families. Messages directed at friends and family of alcoholics are the most effective.

As suggested earlier, you may find that all of these potential target groups - and perhaps others not mentioned in this chapter-are all equally vital to the success of your campaign. Or it may be that some are clearly more important than others. Only you can decide, based on your analysis of the drink driving problem within your own community and the resources available for your campaign. What you must do is rank your potential target audiences, based on a clear understanding of why they are (or are not) important, and what they can (and cannot) do.

Once you have done that, your next step is to determine how you will reach your primary target audiences and what your communications strategy will be for reaching each audience. Suppose that all adults comprise one of your primary targets. You will then have to decide on one or more communications outlets to be used (television, radio, newspapers, direct mail, magazines, or others) and what your message will consist of. One strategy would be to convey facts about the effects of alcohol on a person's ability to drive. Another strategy would be to demonstrate (in a television ad, for instance) one or more acceptable ways to prevent someone who is drunk from driving.

Both strategies and communications outlets will vary, of course, depending on the target audience. You would not, for instance, sponsor a television commercial addressed specifically to police officers, who would constitute a very small percentage of the total television audience. Instead, your message to police officers would be conveyed in their training classes, at meetings of their professional organizations, and so forth.

Similarly, the strategies to be used in conveying your message to police officers will differ from the strategies used for parents or other target groups. You may want both police officers and parents to take seriously their responsibility as role models for young people, but you will not expect them to take exactly the same role.

Before you make any attempt to identify target groups, spend some time studying Appendix A of this booklet. There you will find outlines on each of the 17 target groups mentioned in this chapter. These outlines indicate why each of the target groups is likely to be important in your community, and what your objectives will probably be when you convey your message to any of the groups. These outlines also suggest strategies and potential communication outlets, as well as ways to assess the impact of your campaign.

Assessment may be the last step, but it is just as important a step as those that precede it. Unless you make a determined effort to find out how effectively you have reached your target audiences, you will not be able to conduct more effective campaigns in the future. 


\section{What Every Program Needs: Community Support}

Now comes the problem of figuring out how you can get people to do the things that need to be done.

In most communities, the success of an educational program depends on the active, vocal support and guidance of influential public officials and private citizens who:

- Have the trust and respect of the community or particular constituencies within it;

- Have personal resources or access to resources valuable to the program.

These people include public officials, civic, business, ethnic, racial, and religious leaders, and educators. The mayor, the superintendent of schools, professors at the local university, the publisher of the community's newspaper, and service organization presidents are among the possible contributors of money, technical expertise, and influence. They have access to public service media and to service-oriented volunteer organizations.

Identify these key individuals and explain to them the importance of an educational effort to achieve responsible drinking and driving behavior. Many of the positions held by these influential persons have been identified in other programs. They are listed below, with space provided for you to indicate the name of the person who holds this position or a similar one in your community. There is also space to list what you hope they can contribute.

\section{Key Positions \\ Name of Your Community How They Could Counterpart Be Helpful}

Mayor

City Council

City Manager

Superintendent of Schools 


\section{Assembling Your Policy and Technical Advisory Board}

After identifying the influential people in your community, you can begin to pinpoint particular individuals with influence, expertise, or resources that will contribute to your program. Meetings with various persons having experience with the drinking/driving problem will offer you a variety of viewpoints. For instance, a physician, medical examiner, or pathologist can provide a first-hand description of the effects of alcohol abuse on the human body. A law enforcement official will have a different perspective on the issue. A judge can share knowledge of court procedures and judicial attitudes concerning drunk driving. Use the experience of people like these to help define the scope of the problem.

Persons directly involved with the alcohol safety issue are obvious choices for membership on a policy and technical advisory board. A thorough knowledge of the research on alcohol and driving will enable you to present a convincing case to potential advisory board members.

Seek out people who can be counted on for support throughout the life of the project. Individuals with skills and resources directly related to your program will contribute more than persons who have little to offer besides status or money. Look for board members with special qualifications, such as policymaking authority in local government or in an organization that comes in contact with potential or actual drunk drivers. Other valuable qualifications of board members include access to paid or donated space or time in the public service media, ability to mobilize volunteer groups, and familiarity with various segments of the drinking/driving public.
Key Positions

Name of Your Community

Counterpart

How They Could

Be Helpful
Congressman

Newspaper

Publisher

Public Health

Authority

Head of Local

Alcohol Authority

Head of Retail

Liquor Board

Chiefs of Staff,

Local Hospitals

Traffic Court

Judge

Local Church

Leaders

Ethnic Community Leaders

Jaycees President

United Way

Director

Television Station

Owner

Radio Station

Owner

District Attorney

Head of Social

Service Agencies

Civic

Organization Heads

Church

Organization Heads 


\section{The First Meeting}

Invite potential board members to the first meeting by means of a letter. Describe the extent of the problem in your community and what is being done about it. Reinforce your argument with a presentation of available research and educational materials.

Present the board members with a tentative sketch of what the local program might look like: its objectives, a list of related needs in terms of funding, staff, and resources, and recommendations on how they can assist with the program's design and implementation. Obtain their commitment to the program. Express your thanks for their participation by following up the meeting with a personal letter and a copy of the minutes.

Regular monthly meetings of an active, interested advisory board can be productive. Between meetings, stay in contact with board members to keep up their interest. Seek their help and advice with the program's internal operations, and enlist them as public representatives for your cause.

With good planning and recruitment, your advisory board will be of great value in building an effective public information program. Community support-it's vital.

\section{Key Positions \\ Name of Your Community \\ Counterpart \\ How They Could Be Helpful}

Youth Organization

Heads

High School Student

Leaders

Directors of Other

Public Service

Programs (Heart

Fund, Cancer

Drive, etc.)

Insurance Company

Directors

Noted

Philanthropists

University

Researchers

Advertising Agency

Owners

Printing Firm Owner

Head of Chamber of

Commerce

Heads of Other

Agencies or Pro grams Addressing

Alcohol as a Problem

Plant Managers,

Large Local

Industries 
Sample Agenda For First Meeting of Policy and Technical Advisory Board (Evening Meeting)

7:00 Summarize purpose of meeting.

a. Acquaint members with the problem.

b. Discuss a tentative program.

c. Explore kinds of assistance the board can provide.

7:10 Ask participants to introduce themselves and indicate their occupation.

7:20 Present data on community drinking/driving problem as discussed with local authorities.

You can also present the NHTSA research on alcohol and driving knowledge, attitudes, and behavior, showing factors that may contribute to the problem and how this understanding is useful in planning.

7:45 Show some NHTSA commercials or other materials on drunk driving that emphasize:

a. Severity and scope of the problem;

b. Personalization of the problem

(the drunk driver can be anyone we know);

c. Personal responsibility for preventing drunk driving by those we know;

d. Specific intervention behavior to prevent drunk driving.

8:00 Ask for and answer questions.

8:15 Break for refreshments and to let members absorb the presentation.
8:30 Provide tentative sketch of what program might look like and involve board members in active discussion of program.

a. Have each board member present one of the objectives for group consideration.

b. Present preliminary research plan for analyzing community's drinking/driving audiences: who they are; what they know; how they perceive the problem; what they might be willing to do to prevent it; how they can be reached by mass media or (other) peopleto-people programs; their age, sex, marital status, occupation, TV viewing and radio listening habits. c. Show how research can aid in design of program.

d. Discuss media and other mechanisms for reaching the community.

e. Indicate what types of products, if any, might be produced. Remember that materials adaptable to your program may already exist and all you'll have to develop is a fact sheet describing your local problem and program. f. Suggest criteria for establishing budget, staffing, and resource needs.

9:00 Indicate to board the specific assistance they can provide, individually and collectively.

9.15 Gain agreement on next steps and role of the board.

9:30 Adjourn. 


\section{What Does Your Community Know About Drunk Driving?}

How much does your community know about the effects of alcohol on the body? How much do they know about the extent of the drunk-driving problem? Do people in your area know that car accidents are the number one killer of people under 40? Do they know that alcohol is involved in nearly half of all fatal accidents? What is the drinking pattern in your community? Are people likely to intervene personally to prevent someone from driving when they've had too much to drink? Are people aware of any effort under way to change the attitudes and behavior that contribute to the drunk-driving problem?

The survey's answers to these questions are important in determining what kind of campaign you'll design and at whom you'll direct it. A survey should also indicate if the objectives you defined for the program are on target. The results you obtain from a well-designed survey will enable you to further refine your objectives. The demographic part of your survey will provide specific information about target audiences and behavior and will suggest media strategies to be tried.

Besides contributing planning information, the survey results provide a baseline against which progress can be measured.

\section{Who Can Help You?}

Not everyone knows how to run a survey. But there are people with professional research experience in most communities, and some of them may be willing to help you.

Try a college or university first. College professors may be willing to contribute their time and expertise if they can publish the survey results in a professional journal or turn the task into a class project. If your survey becomes part of a class project, ask the professor to monitor the work closely.

Other potential sources of professional help include marketing research firms and technical research organizations. By all means, try to enlist a person with an evaluation or survey research background to serve on your advisory board.

Professional assistance will increase your chances for collecting valid, useful information. The way questions are worded, persons to be interviewed are selected, interviewers are trained, and the survey is administered and analyzed will affect the quality and reliability of the findings.

\section{Types of Surveys}

Existing public education programs most frequently use telephone, household, or roadside surveys to gather information.

The major factors to consider in deciding what type of survey to conduct include costs, population size of your program area, convenience of administration, availability of staff assistance, and possible biases that may result from different types of surveys.

Table 1, below, summarizes the major advantages and disadvantages of telephone, household, and roadside surveys. If volunteers are used to conduct interviews, the total cost (including analysis of the information) can usually be kept between five to ten dollars per interview.

\section{Telephone Surveys}

In recent years telephone surveys have gained greater acceptance as a reliable method for collecting information. Their primary advantages (and some disadvantages) compared to personal interviews stem from the fact that they're shorter. Because no interview should exceed 15 minutes, you can complete the total survey faster and at a lower cost. But you also sacrifice certain kinds of information. Data that can be gathered by visual aids and by observation are more difficult to obtain over the phone.

Furthermore, people find it easier to refuse a telephone interview than a face-to-face interview. To obtain 500 usable interviews, you may need to call 1,500 to 
Telephone

Comparatively lower cost.

Fast to conduct.

Ease in monitoring.

Convenient for interviewers.

Reliable results obtainable.
Less information can be gathered because of time and impersonal nature.

Respondents may be less representative because of unlisted number, no telephone, and difficulty in collecting extensive demographic data.

Sample size must be as much as three times the usable interviews desired due to higher refusal rate.

Household

Capability to gather more detailed information.

Capability to gather more personal data, e.g., race, drinking habits.

Can obtain most representative sample of community in interviews.

Reliable results obtainable.
Comparatively. higher cost.

Longer time to conduct.

Less direct supervision of interviewers possible.

Interviewers need more extensive training to conduct faster interviews.

Requires more interviewers. More difficult to draw representative sample.
Roadside
Good when specialized sample of driving population is desired.

Provides most reliable measure of actual drinking/driving behavior.

Comparatively short time to conduct; can be completed in four nights-preferably Thurs./Sun., the four heaviest drinking/driving nights of the week.
Comparatively more expensive. Requires specialized staff, including police, breathanalyzer operator.

May encounter legal difficulties.

Less information obtainable because of short time involved in each interview. 
2,000 telephone numbers. Nonetheless, you may find that a telephone survey is the most costeffective and administratively feasible way to gather needed information.

\section{Household Surveys}

If you can allocate more money to discover the community's responses to a larger number of issues, you should consider a household survey. More detailed information among a more representative sample of the community can be collected in a household survey. At the same time, a household survey requires more time and staff resources to design the sample and conduct interviews.

If you conduct a household survey, you will need to select a random sample of census tracts, streets, and houses in order to avoid biasing the results. Also, you must provide intensive training for interviewers to insure that they understand how to conduct interviews properly.

\section{Roadside Surveys}

Roadside surveys are particularly useful when you want to determine the actual pattern of drinking and driving in your community. You need specialized staff, including police officers to stop motorists and technicians to operate equipment that determines the amount of alcohol in the driver's blood. To keep the survey running smoothly and to keep the drivers from getting upset, interviews should be limited to about 20 minutes. Roadside surveys usually should be conducted at night. A survey from Thursday through Sunday is recommended because they're the heaviest drinking and driving days of the week. Because of the extra staff and equipment required, costs will be more than for a telephone or household survey.

\section{The Survey Sample}

Your first survey is intended to identify who in the community is regularly involved in potential drunk-driving situations. In order to pinpoint these people, you will need to survey a sample of the entire community.

The sample should be a representative mix of people of both sexes, beginning with 16year-old youths. Choose persons to be interviewed according to a random selection procedure instead of a deliberate design. This will help eliminate potential biases by insuring that each person in the community has an equal chance of being selected. In order to gather comparable data, samples for follow-up surveys should match that of the initial survey as closely as possible. This does not mean that you should in- terview the same people. It means that you should obtain the same general mix of people.

The exact method of selecting a sample depends on the type of survey you conduct. For a household survey, a random selection of houses from various census tracts works well. For telephone surveys, numbers may be randomly drawn from telephone books or according to a computerized random digit dialing procedure. Roadside surveys involve stopping motorists according to a random pattern at preselected road locations.

A person knowledgeable about evaluation procedures and survey research should be asked to assist with the sample selection, at least for the first survey. The validity and usefulness of your findings will depend on the representativeness and quality of your sample.

\section{Developing A Survey Questionnaire}

Give special attention to the wording, order, and substance of survey questions. Make sure questions are clear enough to get the information you seek. Make sure they don't reflect any bias. In determining their order in the questionnaire, move from general to specific questions. Personal demographic questions should come last.

Before finalizing the question- 
naire, pretest it with a few people to find and remove any problems. You will find it helpful to consult a survey research professional on the design of the questionnaire. (A sample questionnaire designed to discover feelings and actions in drunk-driving situations appears as Appendix B of this manual).

\section{How Many Interviews are Necessary?}

For household, roadside, and telephone surveys, at least 500 completed interviews are necessary for you to make valid judgments about the community's knowledge, attitudes, and certain kinds of behavior.

\section{When to Conduct Interviews}

The best times for household and telephone surveys are weekday evenings (Monday through Thursday) between 5 p.m. and 9 p.m. and weekend days (Saturday and Sunday) between noon and 5 p.m. Interviewing during these hours will maximize the likelihood of acquiring responses from a mixed group of people. If you conduct a survey only during weekday hours, you will obtain a disproportionately high number of women respondents. If you interview on weekend evenings, you may miss a substantial number of people who are somewhere else. Road- side surveys should be conducted Thursday through Sunday nights to maximize the proportion of drivers who have been drinking.

Avoid conducting surveys immediately before, during, or after holiday periods, such as

Christmas, New Year's, Memorial Day, Independence Day, or Labor Day. Both advertising for alcoholic beverages and against drunk driving generally receive greater exposure during these periods, which are usually periods of increased alcoholic beverage consumption. Any survey conducted during these periods is likely to be unrepresentative of the community's standard behavior.

\section{Selecting, Training, and Supervising Interviewers}

In selecting interviewers, be careful to choose persons who are reliable, articulate, friendly, and able to take directions. In the training sessions explain to interviewers exactly what they will be doing, why, and its importance to the community. Make sure they understand all the questions on the questionnaire and the method for choosing persons to be included in the survey.

The interviewers should know how to record responses to each question and what to do if the respondent does not understand a question or prefers not to answer it. Provide each interviewer with written instructions covering:

- Where he or she is to work; - How to determine the house, telephone number, or automobile involved in the first interview; - How to determine subsequent houses, telephone numbers, or automobiles;

- How to list the location or telephone number for which an interview is to be attempted;

- How to record what happens during each interview.

During oral training sessions it is important to go over the questionnaire, inviting the interviewers to ask questions about anything they don't understand. Tell the interviewers:

- How many people are to be interviewed;

- Who is eligible to be inter viewed (the man or woman of house, or children above a certain age);

- How to handle people who refuse to be interviewed, or who refuse to reply to certain questions;

- If, when, and under what conditions an interviewer should "call back" an eligible number;

- Days and hours of work, what to do if they cannot work, what to do with completed interviews, and what to do if they have a problem that can't be resolved from previous instructions.

Have interviewers practice the interview a few times before they begin the actual survey. Have 
them report to a central location each day after they complete their interviews.

\section{Tabulating and Analyzing Survey Responses}

You can save time and increase the accuracy of your analysis if you have the completed survey coded, keypunched, and analyzed by a professional in the data processing field. Most universities and many corporations have computer systems that will do the job. While coding, keypunching, and analyzing a survey do not require extraordinary skills, professional assistance with your first survey will be helpful.

As a general rule, the percentages of persons responding to each of the possible answers for each question will provide a sufficient base for making judgments about the meanings of your survey, results. For example:

\section{QUESTION}

I'd like you to imagine a situa- tion in which a close friend or relative is drunk and about to drive a car. How likely are you to suggest to the friend or relative that you drive him or her home?

$\begin{array}{lrr}\text { Responses } & \begin{array}{l}\text { Number Out } \\ \text { of Total } \\ \text { Responses }\end{array} & \% \\ & & \\ \text { *Extremely } & 332 \text { of } 500 & 66.4 \\ \text { Very } & 117 \text { of } 500 & 23.4 \\ \text { Somewhat } & 31 \text { of } 500 & 6.2 \\ \text { Not at All } & 16 \text { of } 500 & 3.2 \\ \text { No Re } & & \\ \text { sponse } & 2 \text { of } 500 & .4\end{array}$

*Correct Response

\section{Sample Telephone Survey}

In Appendix B, you will find detailed information about constructing a telephone survey and a sample of an actual survey used in public education alcohol safety programs. 


\section{Carrying Out A Campaign That Works}

This chapter discusses communications strategies and messages. After conducting a survey and analyzing the results, you will have a more accurate understanding of your community's participation in alcohol-related situations. This information will enable you to design campaigns and materials around the specific needs of each target audience. Your ability to reach different audiences will increase if you develop materials aimed at each group's unique characteristics.

Experts in the fields of communications and traffic safety research have devoted years to understanding why some public education campaigns work while others fail. The following elements have been present in campaigns that have generated positive effects:

\section{Instructiveness}

The audience must be given a job to do. Lines such as, "Don't Let The Problem Drinker Drive," or "Drunk Driving Kills," do not convey concrete directions about what the audience should do. On the other hand, messages like "If Your Friend Has Had Too Much To Drink, Drive Him Home," or "Serve No More Than One Drink An Hour To A Friend Who Plans To Drive" communicate specific actions a person can take to prevent drunk driving.

\section{Immediacy}

Ideally, messages about driving should reach the driver at the very time when they can be translated into behavior. Automobile radios, billboards, and bumper stickers are media which can reach drivers when they are behind the wheel. After people have been drinking, however, it may be too late to influence them with information. Therefore, alcohol safety campaigns are best designed to help people make wise decisions about driving before the drinking begins.

\section{Relevance}

Receivers of a message should perceive it as personally relevant to them rather than to some ambiguous other person, such as "the problem drinker." People should also clearly understand why the suggested behavior is in their best interest. Persuading an audience that the drunk-driving problem may directly affect them poses a difficult task. Although alcohol-related traffic accidents claim approximately 20,000 lives each year, very few people personally know someone injured or killed in such an accident. Themes that suggest caring and friendship and the responsibility of one person for another offer considerable promise.

\section{Modeling and Social Imitation}

Both drinking and driving are social behavior. They generally do not occur in isolation, but in situations where a person's actions are strongly influenced by his or her perception of the behavior of other people. If group leaders are willing to take personal action to prevent someone they care about from driving while intoxicated, others will follow. Campaigns or messages that concentrate on what people should NOT do are not as effective as those that suggest what people CAN do.

\section{Communications Strategies}

Strategies for reaching the public should focus on how individual activities will meet the program objectives. In deciding strategies for different audiences, you should take into account their particular characteristics and interests.

For example, a strategy for getting physicians to discourage abusive drinking by their patients might include persuading the doctor of his responsibility for patient education.

For youth audiences, consider a strategy of trying to foster peer group responsibility for the actions of members of the group. If you can instill a new standard that views drunk driving as social- 
ly unacceptable behavior, young people will begin to dissuade their companions from deviating from that standard.

You'll find examples of strategies for all previously identified target audiences in Appen$\operatorname{dix}$ A.

\section{Messages and Themes}

Considerable disagreement exists among professionals in the field about the proper tone of public education messages. Factual approaches, humor, guilt, and fear have all been employed, with few evaluations of their impact.

Some psychologists believe that playing on extreme fears (as in a commercial showing a mangled body or suggesting a child being hit by a car) arouses such strong emotion that the audience tunes out the message. Themes aimed at evoking humor or guilt are extremely difficult to handle and can easily be misinterpreted.

Generally speaking, a good approach is to provide specific factual information that tells the audience how to curb drunk driving through personal action in situations familiar to them. While no conclusive evidence exists, such appeals may be more readily adopted than others. They offer the viewer, listener, or reader solid alternatives to drunk driving.
Other themes frequently found in anti-drunk-driving messages concern personal responsibility for a friend's driving behavior (as well as for one's own). They include the suggestion that drunk driving is a serious problem caused by normal people and not just social misfits. The correction of myths about the effects of alcohol is another theme. If your area has a strong and visible enforcement program, the threat of arrest will be an effective theme. If used, however, it must be backed up with action.

\section{Respect Your Audience}

Each target group operates from a different set of assumptions about the world and will respond favorably to messages that fit in with its own frame of reference. Physicians and judges are likely to ignore patronizing pleas. Most young people will reject authoritarian admonitions.

\section{Keep It Short}

Avoid putting too much information into your message. Use only clear, concise statements about drunk driving. Stick to one or two important pieces of information. Otherwise, your message will be unclear, and you will lose your audience. 


\section{Working With The Medial Person-To-Person Presentations}

Creating television commercials or radio messages and giving them wide exposure may seem like the way to spread your message. But the experience of many traffic safety programs suggests that the mass media may not always be the best way to reach your target audiences.

First of all, many people are skeptical of commercial messages. Furthermore, many public service messages are broadcast when the audience is smaller than during prime time hours. If you use mass media, don't rely on it alone. Try to achieve a mix that includes people-to-people presentations. A locally produced commercial, or one obtained from another traffic safety group, can be combined with person-to-person messages before civic clubs, schools, and professional organizations. You can have the greatest impact by influencing the educational programs of other organizations, which in turn are reaching their special audiences.

\section{Communications Outlets}

Deciding which media are appropriate for your program depends on a number of factors. They are:

- Kind of information to be communicated;

- Capability to reach target audience and provoke desired response;
- Size of community;

- Size of target audience;

- Availability of staff resources;

- Production costs.

To select the best media you need to know who your target audiences are - their age, sex, educational level, general life-style, media habits, and stance on drunk-driving issues. This information should suggest certain media outlets and eliminate others. Choose the people and situations to be portrayed in mass media materials carefully.

Young people, for example, are unlikely to be reached by using a middle-aged woman on a television commercial aired during the daytime, but they may identify with a young rock singer on a radio spot. A group of physicians should not be approached through a rock music station if they are more likely to respond to a hospital seminar on alcohol and driving.

Usually you can reach a target audience through more than one communications channel. A target audience will be part of the general audience that can be reached through television, radio, newspapers, magazines, speakers' bureau presentations, etc. It will also be possible to reach a target audience through the specialized media geared to it. Physicians, for example, might be reached by advertisements in medical journals or in materials from their professional organization.
Before selecting your media and developing your campaign, you might contact other organizations which have produced materials on drunk driving. Many of their mass media and collateral materials can be adapted to your local use - and for less than you would pay to produce your own.

The table below describes the advantages and disadvantages of various types of media.

\section{Getting The Media To Use Your Materials}

Before developing new materials, assess your chances of obtaining exposure through mass media and of securing adequate distribution and exposure in other media outlets. Mass media materials can be difficult to place. To gain editors' and broadcasters' confidence, you should familiarize yourself with their operating procedure and preferences. Learn their format, content, and style requirements.

Design a press kit. Include in it a fact sheet on program activities and reproducible photos, artwork. and graphs that give visual impact to the drunk-driving issue and demonstrate the quality of your work.

Above all honor the media's deadline. Broadcasters don't want to hear about your program when they are close to air time; editors are busy people when their deadline is close. The best time to 
Communications Channel

Television

Radio
Advantages

Mass medium for general audience.

Excellent reach.

Visual motion impact with color, sight, and sound.

Editorial and advertising possibilities.

Selectivity-various formats appeal to wide range of audiences.

Flexible time schedules.

Reinforcement capability, especially when played in cars.

Editorial, advertising, and talk show possibilities.

Newspapers/Magazines
Selectivity-specialty publications.

Expanded coverage possibilities through visual means like charts, art, graphs, etc.

Less expensive production costs.

Highly flexible time schedules.

Merchandising possibilities through reprints.

Good credibility.
Stiff competition for public service time.

Inflexible time schedules.

Expensive production costs.

Low message retention value

Advertising time too short for complex messages.

Specialized formats limit general audience reach.

Message time too short for complex information.
Stiff competition for public service space.

Requires local effort and technical know-how, especially writers and press relations specialists. 
Other Media:

People-to-People

Presentations:

Speakers Bureau

Drink-Ins

Fairs

School Assemblies

Halftime Shows

Business \& Labor Programs

Gate Keeper Presentations

Contests
Selectivity-can reach

wide variety of audiences

through tailor-made programs.

Capability to discuss, obtain feedback, answer questions.

Capability to change each time a new need arises; spontaneity.

Can communicate complex information.

Time scheduling flexible; individual programs variable in length.
Can require large amounts of staff time.

Cannot reach large segments of general audience at one time.
Film:

TV Fillers/ Movie Shorts

Educational Films

Trigger Films/Discussion Guides
Useful to augment peopleto-people presentations.

Provocative; encourage discussion.
Costs can run high.

Requires specialized staff, sometime large blocks of staff time.

\begin{tabular}{|c|c|c|}
\hline $\begin{array}{l}\text { Print/Collateral: } \\
\text { Brochures } \\
\text { BAC Cards }\end{array}$ & $\begin{array}{l}\text { Selectivity-can address } \\
\text { specific issue of a target } \\
\text { group. }\end{array}$ & $\begin{array}{l}\text { Only useful as a supplement, } \\
\text { won't suffice as the core } \\
\text { of a campaign. }\end{array}$ \\
\hline $\begin{array}{l}\text { Newsletters } \\
\text { Posters } \\
\text { Transit Cards } \\
\text { Taxi Signs } \\
\text { Outdoor Billboards }\end{array}$ & $\begin{array}{l}\text { Visual capability to suc- } \\
\text { cinctly explain an issue. } \\
\text { Wide and varied distri- } \\
\text { bution possible. }\end{array}$ & $\begin{array}{l}\text { May not be cost effective if } \\
\text { budget is small. }\end{array}$ \\
\hline $\begin{array}{l}\text { Promotional Items } \\
\text { Bill Stuffers } \\
\text { Bottle Bags } \\
\text { Bottle Caps } \\
\text { Breath Testers } \\
\text { Bumper Stickers } \\
\text { Calendars } \\
\text { Coasters } \\
\text { Decals } \\
\text { Key Chains } \\
\text { Matchbooks } \\
\text { Napkins } \\
\text { Pay Envelope } \\
\text { Inserts } \\
\text { Placemats } \\
\text { Litter Bags } \\
\text { Table Tents } \\
\text { Shopping Bags }\end{array}$ & $\begin{array}{l}\text { Selectivity-can address } \\
\text { specific issue of a target } \\
\text { group. } \\
\text { Visual capability to suc- } \\
\text { cinctly explain an issue. } \\
\text { Wide and varied distri- } \\
\text { bution possible. }\end{array}$ & $\begin{array}{l}\text { Only useful as a supplement; } \\
\text { won't suffice as the core } \\
\text { of a campaign. } \\
\text { May not be cost effective if } \\
\text { budget is small. }\end{array}$ \\
\hline
\end{tabular}


talk to editors of afternoon papers is late in the afternoon; for morning papers, it's early in the morning. Television stations make their assignments early in the day, if not days in advance.

When you issue a release, simply give the facts. The media can take it from there. If you are trying to interest a TV station in a background piece, don't insist that it's hard news. Instead, suggest that it's a feature they might be interested in covering. Find out a station's requirements regarding public service announcements (PSAs). Do they prefer 10-second, 30-second, or 60-second announcements?

Here are some opportunities for exposure of your program's activities:

\section{Television}

TV (including CATV and educational channels) presents editorial possibilities, including news coverage of program events and of alcohol-related accidents. Stations may also make editorial time available during public affairs programming. They may invite you to a talk show or interview program.

\section{Radio}

Radio can help your program through news coverage, public service advertising, talk shows, and interviews. Many stations do not have the staff to cover news events. They appreciate getting a press release stating what will be discussed at a news conference, news event, etc.

\section{Print}

When trying to place stories in print, get in touch with the city editor, feature editor, or assignment editor. At television and radio stations, look for the news director. To place PSAs you'll want to introduce yourself (and get to know) the public service director.

\section{People-To-People Communications}

People-to-people communications should play a strong role in your program. They offer the best chance of carrying on an instructive dialogue about the complex problem of drunk driving.

People-to-people methods are portable and flexible. You can speak before a group of industrial workers in the morning, a high school assembly in the afternoon, and a civic organization in the evening (and you can use essentially the same information for each presentation). The audience in these sessions can ask questions about issues of concern to them, and you get immediate and valuable feedback.

You can solidify your relationship with both mass media and with organizations to whom you speak by recognizing their efforts. Always observe their preferred procedures for a program or materials. When justified, present them with awards acknowledging their support of your program.

In general, you can achieve maximum effectiveness if you follow these recommendations: - Find the target audience.

- Determine what is the best communications channel (or channels) to reach the target audience. - Make sure all affordable, appropriate communications channels are utilized.

- Create usable, high-quality, instructive messages the audience can identify with.

- Insure that messages are wellpresented and distributed.

- Follow up your efforts with an analysis of their effectiveness. 


\section{Managing The Campaign}

Once you know whom you want to reach, what you want to say to them, and how you're going to say it, the last task is to manage your financial and staff resources so that you're able to accomplish your objectives. Setting priorities is a particularly critical task. The priority you assign to various projects depends on several factors. The most important are:

- Severity of specific problem; - Likelihood of obtaining high payoff;

- Magnitude of effect desired;

- Time estimated to achieve effect;

- Cost of production or execution;

- Staff requirements.

Good campaign management consists of achieving the maximum impact at the lowest cost in the shortest time using existing staff. With a generous budget and a qualified staff of writers, artists, and evaluators, you may decide to direct major resources into the development and production of your own mass media materials. If you operate on a low budget with only yourself as staff, you should undertake activities that you can complete alone. This will probably mean relying on people-to-people presentations and written press materials, and forgoing television and radio announcements.

One way to expand your program's capabilities is to incorporate the services of volunteers. Professionals with evaluation, broadcast, newspaper, or art experience can augment the skills of your staff. Volunteers from civic organizations, women's groups, schools, and professional organizations can be recruited to do many things, ranging from distributing media materials to conducting interviews or speaking before community organizations. Committed volunteers can make a big difference in the scope of your program when dollars are scarce.

\section{Expenditures}

You will benefit from charting out anticipated expenditures for each campaign you plan to conduct during the next year. Knowing the amount of money available over a year's time, you can begin to decide how best to use the resources. While your efforts should be spread throughout the year, holiday times offer more possibilities for special emphasis. The media often respond more favorably to materials on drunk driving during the period between
Thanksgiving and New Year's.

\section{Coordinating Your Campaign With Others}

Coordinate your efforts with other traffic safety or alcohol abuse groups. Often, you can combine efforts while reducing costs and increasing your chances of obtaining coverage. You also should investigate the schedules for other public service groups, such as the March of Dimes, Cancer Fund, and Heart Association, which set aside a specific week or month for special attention to their cause. Drunk-driving campaigns should be able to obtain their fair share of public service time.

You can contact any of more than 100 organizations that have produced materials to educate the public about drunk driving. For a catalog of these organizations and materials, write to:

\section{Office of Driver and Pedestrain Programs \\ National Highway Traffic Safety Administration}

U.S. Department of Transportation Washington, D.C. 20590 


\section{Evaluating The Campaign}

The best way to find out how successful your efforts have been is to survey the community again, using the same questionnaire that you used to determine community attitudes and behavior before you began the campaign. This second survey should be conducted

within a year after your activities are initiated. You can compare responses from the first and second surveys to determine the effectiveness of your program. The comparison will indicate advances or regressions in knowledge, attitudes, and behavior that may be attributable to your efforts. This knowledge can be used to identify both successful and unsuccessful campaigns and materials.

The suggestions in this manual are based on the collective experience of many different organizations involved in highway safety, especially drinking and driving behavior. Additional consultation is available from:

Office of Driver \& Pedestrian Programs

National Highway Traffic Safety Administration

U.S. Department of Transportation Washington, D.C. 20590 


\section{Appendix A Capsule Communications Plans}

Target Group: Adults involved in alcohol-related situations (Part of General Audience)

Importance: Persons most likely to interact with potential drunk drivers. Most opportunity to intervene to prevent occurrence of drunk driving.

\section{Objectives}

Strategies

1. Provide facts about alcohol

1. Increase knowledge and awareness of the extent, causes, and consequences of excessive drinking in combination with driving.

2. Stimulate acceptance of personal responsibility for preventing the occurrence of drunk driving.

3. Persuade individuals to adopt policy of responsible alcohol use in and outside their own home, alone and with others.

effects on mind, body, and driving skills.

2. Suggest alternatives to heavy drinking at social or business occasions.

3. Develop concept of role model. Show how to act to prevent drunk driving.

4. Demonstrate specific intervention behavior in socially acceptable manner.
The following seventeen charts are capsule communications plans for selected target audiences. They are intended as suggestions only and will need to be adapted to your own community.

4. Increase number of people willing to take action to prevent drunk driving.

Major Issues: Acceptance of responsibility for alcohol/driving behavior of self and other persons in situations where alcohol is served.

Communications Outlet

Assessment of Impact

1. TV.

2. Radio.

3. Print ads.

4. Direct mail.

5. Collateral materials.

6. Organizational meetings (clubs, employers, etc.).
1. Community surveys before and after overall or selected education efforts.

2. Control/experimental groups.

3. Pre/post-tests.

4. Changes in numbers of alcohol-related crashes.

\section{Target Group: Youth (Part of General Audience)}

Importance: Overinvolvement in alcohol-related crashes in relation to their proportion of licensed drivers. Beginning to establish behavior related to drinking/driving.
Major Issues: Willingness to ignore peer group pressure to drink excessively and drive, willingness to give and accept help if intoxicated.

$\begin{array}{llll}\text { Objectives } & \text { Strategies } & \text { Communications Outlet } & \text { Assessment of Impact }\end{array}$

1. Increase knowledge of the extent, causes, and consequences of excessive drinking in combination with driving.

2. Increase perception of risk of accident or arrest if driving under influence of alcohol.

3. Foster willingness to accept help when intoxicated and to give help to prevent a drunk friend from driving.

4. Begin to build new social norm of responsible drinking/ driving behavior.

5. Help examine personal values associated with drinking and driving.

6. Help develop personal skills for making decisions on alcohol issues.
1. Provide factual, nonmoralistic information.

2. Emphasize peer interaction.

3. Offer specific intervention behavior that can be used to prevent drunk driving.

4. Use multi-media approach.

5. Actively involve young people in design and implementation of campaigns.

6. Use speakers who can gain and hold respect of the audience.

7. Educate parents on how to approach young people.
1. Youth-oriented radio.

2. School classrooms.

3. Special assemblies.

4. Clubs.

5. Family settings.
1. Surveys before and after public education efforts.

2. Pre/post-testing.

3. Control/experimental groups. 
Importance: Role models, conveyors of social values related to alcohol and driving.

Objectives

Strategies

1. Appeal to instincts as role

1. Persuade parents to raise issue of drinking/driving with children. model, conveyor of social values.

2. Persuade parents to adopt responsible drinking/driving behavior as role model to children. and well-being of children.
Major Issues: Personal responsibility for teaching and setting example of responsible drinking/driving behavior.

Communications Outlet

Assessment of Impact

1. PTA, other parents groups.

2. Literature from schools.

3. TV.

4. Radio.

5. Print ads.
1. Pre/post-surveys of parents.

2. Pre/post-surveys of children.
3. Provide information on how to talk with children.

\section{Target Group: Hosts and Hostesses}

Importance: Opportunity to encourage responsible drinking/ driving behavior among guests.

Objectives

1. Increase knowledge and awareness of the extent, causes, and consequences of excessive drinking combined with driv. ing.

2. Persuade to adopt measures to discourage intoxication among guests.

3. Convince to intervene with intoxicated guests to prevent them from driving.

4. Stimulate acceptance of personal responsibility for guests' behavior.
Strategies

1. Provide information about alcohol effects on mind, body, driving skill.

2. Provide specific information about measures to discourage intoxication and methods of intervening with intoxicated guests. Present as acceptable social behavior.

3. Provide information about BAC equivalency of various drinks and recognition of impairment.

4. Suggest alternatives to alcohol as focus for social activities
Major Issues: Responsibility for drinking/driving behavior of guests.

Communications Outlet

Assessment of Impact

1. Hostess packets containing information and protein-rich recipes for distribution in supermarkets and liquor stores.

2. Print ads.

3. TV commercials.

4. Radio
1. Community surveys before and after overall or specific education efforts.

Target Group: News Media

Importance: News media are the single most pervasive source of information about the social norms and sanctions related to alcohol.

Major Issues: Coverage or treatment of alcohol use and misuse.

Objectives Strategies

Communications Outlet

1. Media workshops with

1. Provide facts about alcohol effects on body, mind, and driving skills, and consequences of misuse or abuse.

2. Obtain media participation in drafting and adhering to programing code for coverage of alcohol use and misuse.

3. Encourage media to take initiative in helping redefine social norms about alcohol use.

4. Obtain media cooperation in airing or printing public education materials.

28
1. Collect data from news coverage and entertainment programs on the manner in which alcohol and alcoholrelated problems are presented. Present information to media.

2. Persuade key media managers to serve on advisory board. a. management,

b. news staff,

c. program directors, producers, and writers.

2. Meetings of local press club, unions.

Assessment of Impact

1. Pre/post-interviews.

2. Analysis of coverage be fore and after education efforts. 
Importance: Authority to arrest or discretion to ignore drunk drivers, thus determining public perception of the chances of arrest for drunk driving.
Major Issues: Recognition of drunkenness, professional and social responsibility to respond to drunk driving as a serious problem by enforcing pertinent community laws.
Objectives

1. Convince police of severity of drunk-driving problem.

2. Provide information on the symptoms of drunk driving, predisposing factors, court procedures, treatment resources, appropriate manner for handling drunk drivers.

3. Encourage active role in stopping and arresting drunk drivers instead of letting them off with a warning. Seek departmental policy on handling of drunk drivers.

4. Persuade police that their response to drunk drivers establishes the public's percep. tion of the risk of arrest.

5. Convince police to treat drunk-driving teenagers the same as adults.

Strategies

Communications Outlet

Assessment of Impact

1. Convince police of their role as model.

2. Ask police chief or other policymakers to take active role on advisory board.

3. Recruit police to talk to groups of young people.

4. Show police how they are major link in system to rehabilitate people who drink excessively.
1. Police training classes.

2. Roll call.

3. Professional organization meetings.

4. Face-to-face meetings with supervisors.

5. Direct mail.

6. Newspaper and TV features.

\section{Printed materials.}

1. Pre/post-surveys.

2. Analysis of arrest records for volume and characteristics of arrested drunk drivers.

3. Interviews with police chief and individual officers.

\section{Target Group: Lawyers}

Importance: Key contact point for persons involved in legal proceedings connected with alcohol-related traffic accidents prosecution of drunk-driving or public-intoxication offenders, potential elected officials and policymakers.

Objectives Strategies

1. Persuade local lawyers to adopt code of practice that treats drunk drivers as serious offenders who endanger them. selves and other persons.

2. Provide with accurate information about severity of drunk-driving accident problem and responsibility of legal profession to seek reduction of problem through its. work.

3. Provide with information about arrest procedures, court procedures, methods of diagnosing drunk driving, treatment possibilities.

4. Enlist active involvement of prosecuting and defense at. torneys in recommending treatment for offenders with alcohol-related problems.

Major Issues: 1 . Treatment of alcohol-related offenses as serious problems affecting not only the offender but also people around him/her and other innocent individuals.

2. Responsibility to client versus responsibility to society.

Communications Outlet

1. Appeal to them as models for community behavior.

2. Follow their drunk-driving cases to build list of observed behavior.
1. Organized meetings:

a. district attorney's office,

b. public defender's office, c. state and local bar association.

2. Direct mail to lawyers' of fices.

3. Articles in professional journals.

4. Manned exhibit in courtyard area trafficed by lawyers.
Assessment of Impact

1. Pre/post-surveys.

2. Control/experimental groups.

3. Comparisons of lawyers actions in court before and after public education campaigns. 
Importance: Professional group that, by their disposition of drunk-driving cases, have the authority to affirm irresponsible decisions about alcohol and driving or to contribute significantly to a redirection of public behavior toward responsible action. Precedent-setters and policymakers.

Objectives

1. Convince judges that drunk driving is a serious offense.

2. Provide them with information about treatment possibilities.

3. Persuade them to refer drunk drivers to treatment.

4. Obtain cooperation of judges in drawing up and adhering to responsible policies for the disposition of drunk-driving cases. Strategies

1. Appeal to status as precedent setter and policymaker.

2. Record outcomes of drunk. driving arrests over month period to show to judges.

3. Ask traffic court judge to serve on advisory board.

4. Enlist judges to talk before youth and civic groups about the outcome of drunk-driving cases.

Major Issues: Reluctance to treat drunk driving as a serious offense requiring rehabilitation of the offender, or to impose a fine or other punitive action.

Communications Outlet Assessment of Impact

1. Workshops.

2. One-to-one information sessions.

\section{Journal and newspaper} articles.
1. Comparison of disposition of drunk-driving cases before and after public education campaign.

2. Interviews with judges be fore and after public education efforts.

5. Persuade them to positively influence future of persons in alcohol-related legal actions other than drunk driving.

6. Enlist bar association in drawing up and promoting standard policy about responsible use of alcohol among its own members.

\section{Target Group: Physicians}

Importance: Physicians frequently attend to physical disorders of persons with drinking problems. As respected and often revered professionals in their community, they can be influential in persuading persons with alcohol-related problems to seek treatment.
Major Issues: Social and professional responsibility to identify persons with drinking problems and urge them to undertake treatment.
Objectives

1. Establish high level of aware. ness about magnitude of alcohol problems and their relationship to highway safety.

2. Gain acceptance, on individual physician basis, of professional and social responsibility to treat or seek treatment for persons with drinking problems.

3. Obtain cooperation of organizations of doctors and hospital boards in establishing and following a code of conduct related to the identification and treatment of alco. holism and alcohol-related problems.

4. Persuade doctor's groups to adhere to policy of responsible drinking and driving in their own personal lives.

\section{Strategies}

1. Appeal to doctor's selfimage as responsible professional who can provide an invaluable contribution to society.

2. Provide specific information about alcohol-related crashes.

3. Provide professional materials about the treatment of drinking problems and community treatment centers.

4. Ask influential physician to serve on advisory board.

5. Enlist the active participation of doctors in addressing community groups on the alcohol/driving problem.

Communications Outlet

1. Organized meetings:

a. hospital staff, b. local chapter AMA or other professional society, c. medical school classes, d. continuing education courses.

2. Direct mail to physicians' offices.

3. Professional journais, newspapers.
Assessment of Impact

1. Pre/post-survey of random sample of physicians.

2. Comparison of number of monthly referrals to treatment before and after public education efforts. 


\section{Target Group: Pharmacists}

Importance: Authoritative source of information about the effects of alcohol and other drugs and their synergistic effects when mixed together. Important communications channel about these problems for people purchasing prescription and nonprescription drugs.

\section{Strategies}

1. Persuade of position

1. Inform about purpose of community education program, update their information about effects of mixing alcohol with other drugs.

2. Persuade to label prescription drugs with warnings not to mix with alcohol.

3. Encourage to warn patrons orally of dangers of mixing alcohol with other drugs.

4. Recruit to display community education materials in stores. that provides capability to have people listen to advice about drugs.

2. Convince of social responsibility and minimal effort required to fulfill it.

3. Provide information and support for their intervention actions.

4. Recruit for speakers' bureau presentations.

5. Provide materials for distribution and display.

Major Issues: Alcohol mixed with other drugs can be extremely harmful physically and produces intoxication quicker than when consumed by itself.

Communications Outlet

Assessment of Impact

1. Professional Association.

2. Direct mail.

3. Personal visits.
1. Before-and-after comparison of quantity of materials displayed and distributed.

Target Group: Employers and Businessmen

Importance: May be helpful in reaching large audiences. Are aware that much absenteeism from work results from alcohol abuse or misuse. Usually respected in community and serve as models for behavior.

Major Issues: Alcohol abuse or misuse has negative effect on business productivity.

Objectives

1. Inform about severity of problem, give facts about effects of alcohol on body and mind.

2. Obtain suport for office and factory educational programs.

3. Persuade to intervene personally with employees who have alcohol-related problems, helping them obtain treatment.

4. Undertake personal responsibility to control drinking at business functions.

5. Obtain active involvement of groups of businessmen in educating public.

6. Persuade to establish policies about responsible drinking behavior at professional meetings and functions.

Strategies

1. Reduce absenteeism, increase productivity by educating employees and obtaining treatment for those with alcohol problems.

2. Convince employers of their role as leadership models, norm setters.

3. Enlist active involvement of key businessmen on advisory board.
Communications Outlet

1. Employee staff meetings.

2. Pay envelope inserts, posters.

3. Meetings of groups of businessmen, e.g., Jaycees, Kiwanis, etc.

4. Letters from employer.

5. Meetings of employee organizations, e.g., unions.

6. Company publications.

7. Company bulletin and exhibit areas.
Assessment of Impact

1. Pre/post-surveys.

2. Increases in numbers of involved employers and businessmen organizations. 
Importance: Half of youths 14 to 18 report being in alcoholrelated situations once a month or more. Schools and school teachers are dominant influences on the formation of alcoholrelated values. Schools have a captive audience in this age and younger age groups.
Major Issues: About half of all youths say they drink. Many drive drunk or ride with a drunk driver. Teenagers are overrepresented in alcohol-related crashes. Schools, as valueinstilling environments, have a social responsibility to help students make responsible decisions about alcohol use.

\section{Objectives}

1. Get schools to undertake alcohol/driving education program as a regular part of curriculum.

2. Obtain school cooperation in encouraging peer influence in favor of responsible drinking/driving behavior.

3. Provide with information about alcohol's impact on body, mind, and driving skills, symptoms and consequences of alcohol problems, and availability of treatment.

4. Convince teachers and school personnel to suggest alternatives to drunk driving.

5. Persuade schools to treat drinking by teenagers, on or off school premises, as a serious problem.

\section{Strategies}

1. Ask school administrator to participate on advisory board.

2. Persuade school manage. ment that you can help them fulfill social responsibility to inform students about alcohol abuse.

3. Offer curriculum materials and/or speakers to discuss alcohol/driving in classes.

4. Convince school teachers of the importance of their role as models.
Communications Outlet

1. One-to-one meetings with school management.

2. Teacher staff meetings.

3. Printed and audio-visual teaching ajds.

4. Union meetings.

5. Direct mail to school personnel.
Assessment of Impact

1. Pre/post-survey of school personnel.

2. Pre/post-inventory of alcohol-driving curriculum offered in schools.

3. Survey of students.

\section{Target Group: Tavern Owners and Bartenders}

Importance: Daily interaction with drinker/drivers. Power to shut off a patron's alcohol or arrange alternate transportation.
Major Issues: Awareness of risks associated with drunk driving. Responsibility for keeping patrons who must drive from getting drunk. Recognition of impairment.
Ohjectives

1. Increase levels of knowledge about and awareness of causes and consequences of getting drunk.

2. Obtain agreement of tavern owners and bartenders to intervene to prevent drivers from getting drunk or drunk patrons from driving.

3. Persuade tavern owners to display anti-drunk-driving information and to pass along information to patrons.

Strategies

Communications Outlet

\section{Personal visits.}

1. Provide factual informa tion about alcohol/driving including $\mathrm{BAC}$ equivalency between different kinds of drinks; quantity needed to get drunk; how to determine impairment; alternatives to driving drunk.

2. Persuade them of their role in fostering new social norms.

3. Convince them that a loss in sales will not significantly hurt them.

4. Urge them to suggest to patron that he or she stop drinking or switch to nonalcoholic beverages when intoxication seems likely.
2. Meetings with group of tavern owners, informally or in cooperation with state liquor authority.

3. Direct mail.

4. Print ads in newspapers.
Assessment of Impact

1. Personal interviews before and after education effort.

2. Observing behavior in bars before and after education efforts.

3. Informal survey of bar patrons before and after education efforts. 


\section{Target Group: Liquor Store Operators}

Importance: Primary contact point for persons who purchase alcoholic beverages.

Objectives

1. Increase knowledge and awareness of the extent, causes, and consequences of alcohol-related accidents.

2. Persuade to accept some responsibility for encouraging customers to drink and drive responsibly.

3. Persuade to adopt policy of refusing to sell to intoxicated customers and to obtain assistance in finding drunk patrons alternate means of transportation.

4. Recruit to distribute information about responsible drinking/driving to customers.
Strategies

1. Offer bottle bags or other useful product to store owner for distribution with alcohol purchases.

2. Convince owner/operators of their contribution to a responsible drinking/driving society.

3. Convince owner/operator that his participation will not drastically harm sales.

4. Invite owners to speak before civic groups or otherwise stimulate their active participation in education effort.
Major Issues: Acceptance of some responsibility to provide information about responsible drinking/driving to customers who are potential candidates for arrest.
Target Group: Social Workers, Clergy, etc.

Importance: Interaction with persons who have alcohol-related problems.

\section{Objectives}

1. Increase knowledge and awareness of the extent, causes, and consequences of excessive drinking, especially in combination with driving.

2. Inform about appropriate way of relating to problem drinkers.

3. Increase awareness and willingness to refer persons to alcohol treatment facilities.

4. Obtain active involvement in continuing education effort among constituency.
2. Emphasize role as initiator and conveyor of social norms. Also modeling role.
Communications Outlet

1. Personal visits.

2. Informal meetings.

3. Meetings cosponsored by state liquor authority or alcohol distributors.

4. Direct mail.

5. Bottle bags, swizzel sticks, hostess packets, and other collateral materials.
Assessment of Impact

1. Surveys before and after education effort.

2. Random check of behavior when anonymously purchasing alcohol.

3. Personal interview.

4. Random interviews of store customers.
Major Issues: Knowledge about the extent, causes, and consequences of excessive drinking. Willingness to seek treatment for persons with alcohol-related problems and to encourage constituency to drink and drive responsibly.

Communications Outlet

Assessment of Impact

\section{Strategies}

1. Personal meetings with

1. Convince hierarchy of church or social action agency of importance of their involvement. Ask them to cosponsor some education efforts. church or agency management.

1. Surveys before and after education effort.

2. Staff meetings.

3. Printed materials. 
Target Group: Volunteer Organizations (civic, women's, church, social action groups)

Importance: Extensive membership, many of whom host or participate in alcohol-related situations. Sponsorship of many educational activities.
Major Issues: Willingness to undertake activities to inform themselves and persons with whom they interact about responsible drinking/driving behavior.
Objectives

1. Increase level of knowledge about the extent, causes and consequences of excessive drinking.

2. Increase acceptance of personal responsibility to prevent drunk driving by themselves and those with whom they drink.

3. Gain willingness to act as change agent regarding drinking/driving social norms by setting example for responsible behavior and adopting policy of responsible alcohol use.

4. Persuade to undertake educational efforts on behalf of responsible drinking/driving. Provide time and/or money.

Strategies

1. Appeal to role as model citizens.

\section{Persuade of contribution} to society.

3. Provide facts, information about alcohol effects and related responsible decision making.

4. Ask members to speak before other groups.
Communications Outlet

1. Organization meetings.

2. Print ads.

3. Direct mail.
Assessment of Impact

1. Pre/post-surveys.

2. Follow-up interviews with organization officers.

Target Group: Problem Drinkers, Alcoholics, Families of Each.

Importance: Most likely groups to be involved in alcoholrelated accidents. People who are closest to the problem.

Major Issues: Willingness to seek treatment.

Objectives

1. Increase levels of knowledge and awareness about extent, causes, and consequences of drunk driving.

2. Encourage acceptance of fact that problem exists and to seek treatment.

3. Decrease drunk-driving episodes.

4. Increase, among those associated with problem drinkers and alcoholics, willingness to intervene to help them obtain treatment.

\section{Strategies}

1. Provide facts about alcohol's effects on body, mind, driving skill.

2. Provide information about treatment facilities.

3. Provide support for intervention to treat problem.

4. Provide information about specific intervention behaviors to prevent a drunk from driving.
Communications Outlet

1. AA, other alcoholic groups.

2. Physicians, social workers, clergy, other counseling groups, employers, bartenders, liquor store operators.
Assessment of Impact

1. Before-and-after comparison of records of treatment facilities and police records.

2. Pre/post-community. surveys. 


\section{Appendix B A Sample Telephone Questionnaire}

\section{Survey Background Information}

This is a sample telephone survey questionnaire that you can use, with minor adaptations, in your own community. The questions cover many knowledge, attitude, and behavior issues concerning drunk driving. It was originally designed to elicit information about people's willingness to take intervention actions to prevent the occurrence of drunk driving. The correct response to a question is indicated by an asterisk(*). The numbers to the right of each response are a keypunch code you can use if you decide to tabulate results by computer.

\section{Target Audiences - Demographic Questions}

Some of the questions that follow ask about characteristics of the general population that will help identify your program's target groups. These groups will consist of persons or groups of persons who are most frequently involved in occasions where alcoholic beverages are served and thus most likely to encounter drunkdriving situations. The demographic questions are indicated by (D) in the lefthand margin.

\section{Knowledge About Alcohol and Its Effects}

Questions to determine the levels of knowledge about alcohol's effect on the mind, body, and driving skills are indicated by (KAE) in the lefthand margin. While it is unlikely that good information alone will result in good behavior, your community education program will nonetheless wish to correct mistaken myths and inaccurate assumptions about alcohol.

Questions addressing community perceptions about the severity of the drunk-driving problem and the laws governing legal intoxication limits are indicated by (KDD) in the lefthand margin.

\section{Attitudes Toward Drinking and Driving}

Questions that indicate how people feel about their own drinking and driving behavior and their societal obligations to prevent drunk driving by others are preceded by $(A)$ in the lefthand margin.

\section{Drinking, Driving, and Intervention Behavior}

Among the essential information you should collect are data on the drinking behavior of the community. If a large proportion of the population drinks heavily and frequently, information about this behavior should strengthen your prospects for gaining official support. Because much public controversy has built up in recent years about the collection of such personal information, you should be sensitive to possible objections about gathering it. Relevant survey questions are indicated by $(B)$ in the lefthand margin.

\section{Awareness of The Community Education Program}

Questions that reveal the community's awareness of the program are indicated by $(\mathrm{KP})$ in the lefthand margin.

\section{Sample Telephone Survey}

Introduction

Read: Good (morning/afternoon/evening). My name

is _ـ We are conducting a survey for IGovernment Department, Such as Los Angeles County, or Academic or Research Organization.

Interviewer: Use Your Quota Sheet to Determine if You Need a Male or Female Respondent.

Read: May I speak with a person (Male, Female as Needed to Fill Quota) present now in your household who is 16 years of age or older?

$$
\text { Yes..... [ ] No..... [ ] }
$$

Selected Respondent is:

Male ...... [ ]

Read: I would like to ask you a few questions. Your responses will be very valuable and will remain strictly confidential. They will be used for statistical purposes only.

\section{Reintroduce Yourself, If Neccessary, And Continue....}

Read: There are many problems and social issues facing our country at this time. I'd like to know how important you feel some of them are.

1a. How important a problem do you think crime in the streets is?

Extremely important .... [ ] 1

Very important ....... [ ] 2

Somewhat important .... [ ] 3

Not at all ......... [ ] 4

1b. How important a problem do you think drug abuse is?

Extremely important .... [ ] 1

Very important ....... [ ] 2

Somewhat important .... [ ] 3

Not at all ......... [ ] 4

1c. How important a problem do you think drunk driving is?

Extremely important .... [ ] 1

Very important ....... [ ] 2

Somewhat important .... [ ] 3

Not at all ......... [ ] 4 
2. Read: I would like to talk to you about occasions where alcoholic beverages are served.

2a. In the past three months, have you been in a situation where alcoholic beverages were served?

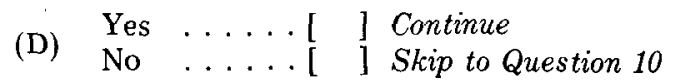

2b. Which one phrase best describes how often you found yourself in this type of situation in the past three month period? Would you say it was ?

Read List Until You Get An Answer'

Daily $\ldots \ldots \ldots \ldots \ldots \ldots \ldots \ldots \ldots$

$2-6$ times a week ....... [ ] 2

(D) Once a week ......... [ ] 3

Once every 2 or 3 weeks .... [ ] 4

Once a month ......... [ ] 5

Less than once a month ... [ ] 6 Skip to Question 10
3. Read: I'm going to read you a series of statements describing some aspect surrounding the use of alcoholic beverages. Do you strongly agree, somew hat agree, somewhat disagree, or strongly disagree with each statement?
Read Statement Followed By: Do You Strongly Agree, Do You Somewhat Agree, Do You Somewhat Disagree, Do You Strongly Disagree.

\begin{tabular}{|c|c|c|c|}
\hline $\begin{array}{l}\text { Strongly } \\
\text { Agree }\end{array}$ & $\begin{array}{l}\text { Somewhat } \\
\text { Agree }\end{array}$ & $\begin{array}{l}\text { Somewhat } \\
\text { Disagree }\end{array}$ & $\begin{array}{l}\text { Strongly } \\
\text { Disagree }\end{array}$ \\
\hline 1 & 2 & 3 & 4 \\
\hline$\left[\begin{array}{ll}{[} & 1\end{array}\right.$ & {$\left[\begin{array}{ll}1 & 1\end{array}\right.$} & {$\left[\begin{array}{ll}1 \\
\text { ] }\end{array}\right.$} & {$[\mathrm{x}]$} \\
\hline$\left[\begin{array}{ll}1 & 1\end{array}\right.$ & {$\left[\begin{array}{ll} & ]\end{array}\right]$} & {$\left[\begin{array}{ll}1 & ]\end{array}\right.$} & {$[\mathrm{x}]$} \\
\hline$[\mathrm{x}]$ & {$\left[\begin{array}{ll}1 \\
\text { ] }\end{array}\right.$} & {$\left[\begin{array}{ll} & ]\end{array}\right]$} & {$\left[\begin{array}{ll}\text { ] } \\
\text { ] }\end{array}\right.$} \\
\hline$[\mathrm{x}]$ & {$\left[\begin{array}{ll}\text { l } \\
\text { ] }\end{array}\right.$} & {$\left[\begin{array}{ll} & ]\end{array}\right]$} & {$\left[\begin{array}{ll}\text { l } & \text { ] }\end{array}\right.$} \\
\hline$\left[\begin{array}{ll}{[} & ]\end{array}\right.$ & [ ] & {$\left[\begin{array}{ll}\text { l } & \text { ] }\end{array}\right.$} & {$[\mathrm{x}]$} \\
\hline$\left[\begin{array}{ll}\text { ] } \\
\text { ] }\end{array}\right.$ & {$\left[\begin{array}{ll}\text { l } & \text { ] }\end{array}\right.$} & {$\left[\begin{array}{ll}1\end{array}\right]$} & {$[\mathrm{x}]$} \\
\hline
\end{tabular}

Interviewer: Make Sure You Have Asked All Phrases

4. Read All Questions - But Do Not Read List on Question $4 f$. 4a. In the past month, have you discussed with anyone the topic of drunk driving?

(B) $\quad \begin{array}{llll}\text { Yes } & \ldots & {[\mathrm{x}]} & 1 \\ \text { No } & \ldots & \ldots\end{array}$

4b. In the past year, were you in a situation where someone had been drinking too heavily and was about to drive a car?

(B) $\begin{aligned} & \text { Yes } \ldots \ldots[\text { [ ] } 1 \\ & \text { No } \ldots \ldots\end{aligned}$

4c. How many times would you say this happened in the past three months? number

Past three months

$4 \mathrm{~d}$. In the most recent situation, did you take any kind of action to stop the drunk person from driving?

(B) Yes ..... [ ] 1 Ask Question 4e 4e. Please tell me what actions you took?

Do Not Read List - Check Off Answers
Drove the person home $\ldots \ldots \ldots \ldots[$ ] 1

Offered to drive him/her home ....... [ ] 2

Offered to let him/her stay over ....... [ ] 3

Called a taxi $\ldots \ldots \ldots \ldots \ldots \ldots \ldots$ ] 4

Took his/her keys away ........ ] 5

Physically restrained him/her....... [ ] 6

Got someone else to drive them ....... [ ] 7

Gave him/her coffee $\ldots \ldots \ldots \ldots$ [ ] 8

Gave him/her a cold shower ........ [ ] 9

Gave him/her food ............ [ 110

Called the police ............ [ ]11

Other [ $\quad] 12$ 
5. Read: I'd like you to imagine a situation in which a close friend or relative is very drunk and is about to drive a car.

For Each Phrase Read:

How Likely Are You To

Extremely, Very, Somewhat, Not At All. $?$
a) Suggest to the person that you drive him home? . . . .
(B) b) Suggest to the person that he stay overnight at

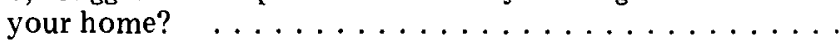
c) Call a taxi for the person who drank too much .......
d) Take the person's keys away
e) Get assistance to restrain the person

$\begin{array}{ll}{[} & 1 \\ {[} & ] \\ {[} & ] \\ {[} & ] \\ {[} & ]\end{array}$

[ ] [ ]
[ ]
$\left[\begin{array}{llll}1 & 1\end{array}\right]$
$\left[\begin{array}{lllll}1 & 1 & {[} & 1\end{array}\right]$
$\left[\begin{array}{llll}1 & 1 & 1 & {[}\end{array}\right]$

[ ] [ ]
[ ]

Extremely

Very

Somewhat

Not At All

1

2

3

4

6. Now using the same phrases, I would like you to think of yourself as giving a party. How likely are you to

\begin{tabular}{|c|c|c|c|}
\hline $\begin{array}{c}\text { Extremely } \\
1\end{array}$ & $\begin{array}{l}\text { Very } \\
2\end{array}$ & $\begin{array}{c}\text { Somewhat } \\
3\end{array}$ & $\begin{array}{l}\text { Not All All } \\
4\end{array}$ \\
\hline$\left[\begin{array}{ll}\text { l } \\
\text { ] }\end{array}\right.$ & {$\left[\begin{array}{ll}{[} & ]\end{array}\right.$} & {$\left[\begin{array}{ll} & ]\end{array}\right]$} & {$\left[\begin{array}{ll}\text { ] } \\
\text { ] }\end{array}\right.$} \\
\hline [ ] & {$\left[\begin{array}{ll}{[} & ]\end{array}\right.$} & {$\left[\begin{array}{ll}{[} & ]\end{array}\right.$} & {$\left[\begin{array}{ll}\text { l } \\
\text { ] }\end{array}\right.$} \\
\hline [ ] & {$\left[\begin{array}{ll}{[} & ]\end{array}\right.$} & {$\left[\begin{array}{ll}1 & ]\end{array}\right.$} & {$\left[\begin{array}{ll}1\end{array}\right.$} \\
\hline$\left[\begin{array}{ll}1\end{array}\right.$ & {[]} & {$\left[\begin{array}{ll}\text { ] } & \text { ] }\end{array}\right.$} & {$\left[\begin{array}{ll}1 & ]\end{array}\right.$} \\
\hline$\left[\begin{array}{ll}{[} & ]\end{array}\right.$ & {$\left[\begin{array}{ll}{[}\end{array}\right]$} & [ ] & {$\left[\begin{array}{ll}1 & ]\end{array}\right.$} \\
\hline
\end{tabular}

7. If you and another person are going to a party, how likely are you to agree ahead of time that one of you will limit your drinking and drive home? ................

8. 8a. Do you recall having seen or heard any drinking and driving advertising in the past few months?

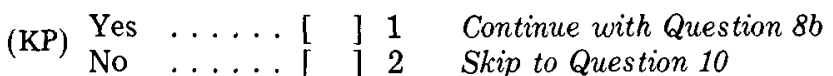

8 b. Where did you see or hear it?

Read List - May Have More Than One Answer.

Radio ........ [ ] 1

Magazine $\ldots \ldots \ldots[\text { ] }]_{2}$

(KP) Newspaper....... [ ] 3

TV ......... [ ] 4

Radio and TV ..... [ ] 5

Other $\frac{}{\text { (specify) }}[] 6$ 8c. What was the message about?

Don't Read List - Check Off Responses Given.

People should know how much they can drink before driving .............. [ ] 1

Many fatal crashes are caused by drunk drivers ................. [ ] 2

People who give parties should see that their friends don't drive home drunk ........ [ ] 3

If you are really a person's friend you'll stop him from driving drunk, no matter how reluctant you are .............. [ ] 4

More police are patrolling the streets at night to watch for and arrest drunk drivers ..... [ ] 5

Other $\ldots \ldots \ldots \ldots \ldots \ldots \ldots \ldots \ldots \ldots \ldots$ 
$8 d$. As a result of seeing this advertisement are you likely to take some kind of action in a drinking situation that you may have not taken before?

(KP) ${ }_{\text {Yes }} \ldots \ldots[$ [ ] 1

9. Though you may have mentioned it before, do you remember seeing an ad where:

a. A husband and wife rush off to the hospital to see a friend who has been in an accident .............. [ ] [ ]

b. A woman is talking about her friend who always drank too much after

c. A group of men in a car coming home from a card game . . . . . . . . . .

(KD)

d. A women in bed who is worried about her brother's drinking and the phone

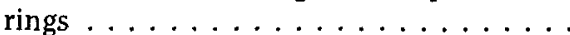

e. A man telling how he saved his friend's life by having him stay over instead of driving drunk

f. Bartender describes sending a drunk customer home in a taxi

g. A women tells how she drove an intoxicated guest home

$$
12
$$
painting class $\ldots \ldots \ldots \ldots \ldots \ldots \ldots \ldots$ [ ] [ ]

Do Not Read List! Check Off Responses Given

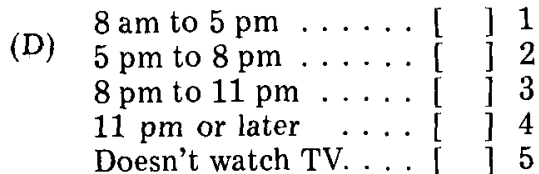

12. On an average day, during what hours do you listen to the radio?

Do Not Read List! Check Off Responses Given

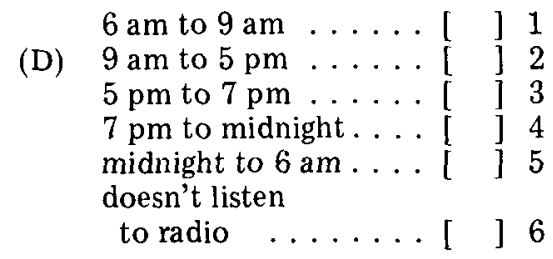

This survey is sponsored by the

Thank you for your cooperation.

Phone \#

Interviewer

Date

\section{Suggested Additional Questions For Surveys}

The questions below are suggested for use in surveys if one of the areas underlined is addressed by program activities.

\section{Alcoholdriving problem recognition}

1. Which one of the following circumstances do you feel causes the greatest number of automobile accidents?

16 through $21 \ldots \ldots[$ ] 1

22 through $24 \ldots \ldots \ldots[] 2$

(D) 25 through $34 \ldots \ldots[$ ] 3

35 through $49 \ldots \ldots$ [ ] 4

50 and over. ...... [ ] 5

Refused........ [ ] 6

10b. Are you:

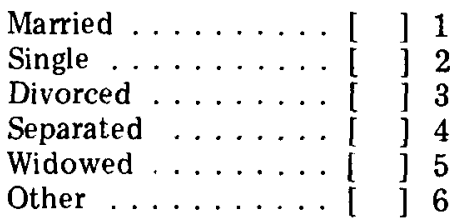

10c. Do you drive?

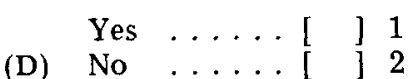

11. On an average day during what hours do you watch television?
a. Unsafe highways or streets
b. Driving too fast
c. Driving under the influence of alcohol
d. Disregard for traffic regulations by drivers
e. Drivers who handle a car poorly

2. What do you think the term BAC, Blood Alcohol Concentration, or Blood Alcohol Level means?
a. Answer completely correct
b. Answer essentially correct
c. Answer incorrect
d. Don't know

3. When you expect to drive after an occasion where alcoholic beverages are to be served, do you think about how many drinks you will have?
a. Always
b. Usually
c. Sometimes
d. Never

Personal drinking/driving behavior 
4. In the past three months, have you refused to drive or decided not to drive because you thought you had drunk too much?

a. Yes

b. No

5. If you drive after drinking too much, what are your chances of being stopped by the police?
a. Very high
b. High
c. About even (50-50)
d. Low
e. Very low
f. Don't know

\section{Program recognition/official support}

6. Would you, as a citizen, support each of the following actions, if it was proposed by public officials?

Answer:

a. Yes I would support it

b. No, I would not support it, or

c. I don't know
a. Greater police enforcement of drunk-driving laws
b. A large scale public information and education campaign on drunk driving
c. More severe penalties for
d. Having convicted drunk drivers use a pill which causes them to be sick if they drink alcohol

7. Have you read about or heard of a campaign or program in the area that is trying to reduce alcohol-related traffic deaths?
a. Yes
b. No
c. Your organization*
b. Other
c. Can't recall

8. (If answer above is Yes, ask the following:) Do you recall what agency or organization is sponsoring the program. 


\section{Bibliography}

Cutlip, Scott M., and Center, Allen. Effective Public Relations. Englewood Cliffs, N.J: Prentice Hall, 1964.

Dexter, Lewis A., and White, David. People, Society and Mass Communications. Toronto: Collier-Macmillan, 1964.

Flesch, Rudolf. The Art of Readable Writing. New York: Harper and Row, 1974.

Grey Marketing and Research Department, Grey Advertising Inc. "A Strategic Study on Alcohol and Highway Safety: Volume I, Adults 18-55." Report prepared for the Office of Driver and Pedestrian Programs, National Highway Traffic Safety Administration, U.S. Department of Transportation. January, 1974. Contract No. ADM 41-74-0022.

"A Strategic Study on Alcohol and Highway Safety: Volume II, High School Youth." Report prepared for the Office of Driver and Pedestrian Programs, National Highway Traffic Safety Administration, U.S. Department of Transportation. January, 1974. Contract No. ADM 41-74-0022.

Karlins, Marvin, and Abelson, Herbert. Persuasion: How Opinions and Attitudes are Changed. New York: Springer, 1970.

Klein, Ted, and Danzig. Fred. How to Be Heard: Making the Media Work For You. New York: Macmillan, 1974.

Levy, Clifford. A Primer for Community Research. San Francisco: Far West Research Inc., 1972.

Marston, John E. The Nature of Public Relations. New York: McGrawHill, 1963.

National Association of Broadcasters, "If you Want Air Time." Washington, D.C.: NAB, 1974.

Parten, Mildred. Surveys, Polls and Samples: Practical Procedures. New York: Cooper Square, 1950.

Schramm, Wilbur, and Roberts, Donald. The Process and Effects of Mass Communications. Urbana: University of Illinois Press, 1971.

Suchman, Edward. Evaluative Research: Principles and Practice in Public Service and Social Action Programs. New York: Russell Sage, 1967.

U.S., Congress, House, Committee on Public Works. 1968 Alcohol and Traffic Safety Report. 90th Cong., 2d Sess., 1968.

U.S. Department of Transportation, National Highway Traffic Safety Administration, Office of Driver and Pedestrian Programs. The Use of Mass Media for Highway Safety. Washington, D.C.: U.S. Department of Transportation, DOT HS-801 209, June, 1974.

Webb, Kenneth, and Hatry, Harry P. Obtaining Citizen Feedback: The Application of Citizen Surveys to Local Govermments. Washington, D.C.: The Urban Institute, 1973.

Weiner, Richard. Professional's Guide to Public Relations Services. 2d ed. New York: Richard Weiner Inc., 1975. 


\section{Other Suggested Resources}

\section{Periodicals/Communications}

Advertising Age, a weekly trade paper covering advertising, marketing, and promotion. Published by Crain Communications, Inc., 740 N. Rush St., Chicago. Ill. 60611.

Subscription: $\$ 25$ per year.

Broadcasting, a newsweekly of the broadcast and allied industries. Published by Broadcasting Publications, Inc., 1735 DeSales St. NW, Washington, D.C. 20036.

Subscription: $\$ 25$ per year.

Channels, a monthly newsletter published by the National Public Relations Council of Health \& Welfare Services, 815 2nd Ave., New York, N.Y. 10017. Covers all subjects of interest to people in promoting nonprofit, social welfare causes.

Subscription price, plus membership in the Council: $\$ 25$ per year. Editor and Publisher, a weekly trade magazine covering the fields of newspaper publishing, advertising, and public relations. Published by Editor and Publisher Co., 805 Third Ave., New York, N.Y. 10022.

Subscription: $\$ 10$ per year.

The Public Relations Journal, published monthly by the PRSA, 845 Third Ave., New York, N.Y. 10022. Contains articles on all facets of communications.

Subscription: $\$ 9.50$ per year for nonmembers.

\section{Pamphlets/Communications}

PRSA Loan Library: A variety of pamphlets and arrticle reprints on all phases of public relations and communications is available for free or a modest charge from the librarian at PRSA, 845 Third Ave., New York, N.Y. 10022. Catalog of information topics available.

\section{Reference Sources/Communications}

*Broadcasting Yearbook, data on radio and TV media and markets across the country. Published by Broadcasting Publications, Inc., 1735 DeSales St., NW, Washington, D.C. 20036. Purchase Price: $\$ 17.50$ per annual copy.

*Editor and Publisher, The International Yearbook. Published by Editor and Publisher Co., 850 Third Ave., New York, N.Y. 10022. A directory of the newspaper industry in the U.S. and Canada with circulation, ad rates, and editorial information.

Single Copy: $\$ 20$.

*Standard Periodical Directory, a reference manual published biennially listing periodicals published on a regular basis in the U.S. Oxbridge Directories, Inc., 150 E. 52 Street, New York, N.Y. 10022.

Price $\$ 60$.

Materials Catalog, lists promotional materials, articles and reports, and newsletters pertaining to highway safety. Published by Public Communication Group, Highway Safety Research Institute, The University of Michigan, Ann Arbor, Mich. 48105. Free.
*Standard Rate and Data Service, 5201 Old Orchard Rd., Skokie, Ill. 60076. Lists rates and market data for broadcast networks, newspapers, spot radio and TV, and transit media. Each book must be purchased individually, making them expensive for most small organizations. However, libraries, ad agencies, and the media should have copies.

\section{Periodicals/Highway Safety}

Annual Report on the PI\&E Countermeasure of ASAPs and The Use of Mass Media For Highway Safety, two manuals published by NHTSA's ODPP. U.S. Department of Transportation, Washington, D.C. 20590. The latter publication has an extensive bibliography of articles and research papers on the subjects of public information and traffic safety.

Highway User, a quarterly magazine published by Highway Users Federation at 1776 Massachusetts Ave., NW, Washington, D.C. 20036.

Price: $\$ 3$ per year.

National Traffic Safety Newsletter, a monthly publication of the NHTSA, reporting on many phases of traffic safety, public information, and meetings of transportation officials. Free by writing: National Traffic Safety Newsletter, 4102 Nassif Building, Washington, D.C. 20590.

The Reporter, published monthly by the Highway Users Federation, 1776 Massachusetts Ave., NW, Washington, D.C. 20036. Reports on topics of interest to road users as well as managers. Free.

Traffic Safety, published monthly by the National Safety Council, 425 N. Michigan Ave., Chicago, Ill. 60711. A national magazine dealing with traffic accident prevention.

Subscription: $\$ 5.90$ per year. 